\title{
ANDEAN METAPHYSICAL CONCEPTS AND THE ROLE OF IMAGERY IN CATHOLIC RELIGIOUS INSTRUCTION
}

\author{
CONCEPTOS METAFÍSICOS ANDINOS Y EL ROL DE LAS IMÁGENES \\ EN LA INSTRUCCIÓN DEL CATOLICISMO
}

\author{
Marietta Ortega Perrier*
}

\begin{abstract}
This article aims to contribute to the discussion about social and ideological change in the Andes and the impact that religious images may have had on it. It refers to my understanding of ethnographic material collected in northern Chile on the highlands of Tarapacá (3.800-4.200 m.), among Aymara people. The outcome of several years of participant observation beginning in mid1978, remained largely unpublished. Nowadays most of the Aymara population of Chile lives in towns and are no longer herders and subsistence agriculturalists. I suggest that some ideological processes of which I became aware at that time had great impact on social changes that occurred since, which justifies reviewing them at present.

Based on ethnographic material and secondary data I bring about similarities between native Andean ideological concepts with Catholic theology prevalent at the time of Evangelization. Religious images were a privileged means by which the Church attempted the conversion of illiterate Indians and the "material evidence" of the teachings left behind, once the priests abandoned the territories. Elsewhere I analyzed in depth how ritual, more precisely "ritualization" made possible the appropriation of foreign material and ideological elements. In this paper, I mention how fiestas de santos provide an occasion to enact ritual, particularly the "ritual stance" and thus provides an occasion for the appropriation of foreign symbolic elements. Finally, I present four examples of resemblance between Andean and ancient Catholicism beliefs as represented graphically. These are the human soul, the Scaling to Heavens, the Virgin Mary and the origin of rain, and Saint Barbara's representation of Saint James ${ }^{1}$.
\end{abstract}

Key words: Ritualization, catholic images, ideology, social change, Aymara.

Este artículo tiene la intención de contribuir a la discusión acerca de los cambios ideológicos y sociales en los Andes y el impacto que las imágenes religiosas pueden haber tenido en ellos. Los planteamientos siguientes se basan en material etnográfico recogido entre los Aymara en el altiplano de Tarapacá durante distintas temporadas de observación participante a partir de 1978, cuyos resultados han permanecido mayoritariamente sin publicar. En la actualidad la mayor parte de quienes se declaran Aymara vive en las localidades costeras y no se dedica a la ganadería y agricultura de subsistencia. Se postula que muchos de los procesos presenciados durante esos años de trabajo de campo tuvieron gran impacto en la situación actual de las comunidades de origen y en quienes habitan las ciudades.

Acudiendo a fuentes secundarias y etnográficas, se destacan similitudes existentes entre conceptos ideológicos prevalentes en el mundo andino contemporáneo y la teología católica del tiempo de la Evangelización. En este proceso, las imágenes religiosas fueron medios privilegiados para la conversión de la población indígena, imágenes que permanecieron cuando los sacerdotes abandonaron los territorios más remotos. Se postula que la "ritualización" expresada en las fiestas de santos provee la oportunidad para la apropiación y reinterpretación de elementos simbólicos ajenos. Finalmente, se presentan cuatro ejemplos de las similitudes aludidas: el Alma, las Escaleras al Cielo, la Virgen María y el origen de las lluvias, y la representación de San Santiago por Santa Bárbara.

Palabras claves: Ritualización, imaginería católica, ideología, cambio social, Aymara.

\section{Introduction}

Santo Tomás de Isluga is the name of a territory and a Community located at 3.800-4.200 meters above sea level, on the highlands of Tarapacá. At the time of my first period of fieldwork, the population reached a total of approximately 1.200 people disseminated on a vast territory (20.000 has) and the people of Isluga, islugueños, spoke Aymara and Spanish as second language. Still, older women could be solely Aymara speakers.
Islugueños were mainly herders of camelids (alpacas and llamas) subsistence agriculturalists of potatoes and quinoa and by mid 1980s produced some garlic for export. Relationships of complementarity between them and the people of the fertile valleys (precordillera) were active, whether by bartering local products or by obtaining money working as seasonal laborers (Sols [1975] 20011). The territory had been first under Colonial rule, later became part of the Peru and after the Nitrate War (1879-1883), it became part of Chile's. The existence of Isluga

\footnotetext{
* University of Tarapacá, Department of Anthropology. Arica, Chile. Correo electrónico: mortega@ uta.cl
} 
as a discrete entity -corporately owned, is a leaflet published in 1918 where the local caciques (heads of the Community) asked the Chilean Government for the recognition of Property Titles and landmarks supported by documents from 1612 and 1754 (González, Gunderman, Hidalgo 2014: 238-239).

Between the late seventies and the mid-nineties albeit democracy was reinstated in 1990, the political and ideological apparatus of the dictatorship was able to reach and settle on the highlands of Tarapacá in a way that was not possible before. Moreover, by applying the new administrative structure Santo Tomás de Isluga became Comuna de Colchane with a police officer as Major of the Municipality. The time elapsed since I last worked in Isluga and the valley of Camiña reassured my perception of having been witness to a crucial period, in fact a turning point, for the people of Isluga. The pervasiveness of Chile's nationalistic views was blatantly increased in schooling, local government and economy, as well as in the realm of ideology in the sense of religious beliefs and practices.

During less extensive visits during the late nineties, early and mid-2000s I was able to appreciate substantial changes. Among others, the decrease on population numbers due to migration to the coastal towns and valleys, and the transition from herding to purchasing trucks or vans in the Free of Tax Zone in Iquique, the coastal town. Many Islugueños became drivers in charge of moving imported goods to Bolivia and a few of them or their children became involved in smuggling cocaine, as police records show. Similarly, I was aware that the return to democracy in 1990 did not mean a substantial turn for the best in terms of social validation of the Islugueño Aymara identity. In fact, in spite of changes on the democratic election of local authorities (major and council officers), the promulgation of the Indian Law in 1993 and further efforts, Islugueño life was deeply changed as it remains now. Nationalism and geopolitics made islugueño people and their mode of life, redundant.

Needless to say that I understand change as inherent to Islugueño life and that they have been part of wider ethnic and later mercantile circuits of different sorts. I suggest that one of the ways in which Isluga survived different administrative and political regimes was through the practice of ideological strategies that allowed the re appropriation and incorporation of symbols and practical innovation. One of these ways was the practice of ritualization, a particular kind of action. And although the dramatic changes experienced, many of the resources exhibited by today Aymara urban citizens may be illuminated by this analysis of the past.

\section{How changes become tradition. Costumbre as Ritualization}

When asked about the reasons for performing certain rituals, Islugueños will reply, '... it is costumbre...' Similar actions were performed to propitiate different entities in what seemed to be choreographed variations of archetypal steps. During ritual performances, I tried to establish linear sequences only to be frustrated by what seemed to be an enormous variability of arrangements, all of which were considered 'correct' as costumbre. In addition, many everyday activities, such as the killing of an animal for food, incorporated a series of actions reminiscent of ritual sacrifice, and vice versa. Planting potatoes in the nearby fields was also preceded by ritual. However, when asking my friends about what they were doing, I was taken aback by the exiguity of their explanations or their stereotypical replies. When contrasting my data with the literature about neighboring countries, I felt somewhat defeated by this seeming lack of exegesis and by the 'poverty' of the Islugueños' ritual performances. Moreover, how was I to explain the ease with which the same ritual procedure was transferred from, for example, the marking and the blessing of llamas to that of newly acquired vans and trucks? Here I was not interested in explaining the reasons for this transference but rather in the ways in which this transference was made possible. I felt that the reply to these questions was central to explaining the ways in which Islugueños have dealt with social change as a more comprehensive phenomenon.

The term costumbre came into Islugueños' explanations so often that I decided to assume the importance of this term and found out that Humphrey and Laidlaw's theory of ritualization can be used to understand the working of Islugueño ritual (Ortega Perrier 2006). In fact costumbre shares the attributes that allow for the transformation of ordinary action into ritual: it is non-intentional, it is stipulated, it is archetypal and, finally, costumbres are felt as external to the performers, i.e., 'apprehensible' (Humphrey and Laidlaw 1994: 89). Regarding ritual as action provides a framework to explain how ritual may 
re-interpret non-Islugueño concepts and yet later see them as part of 'tradition'?

I also followed Islugueños' use of the word as having two main aspects: costumbre as ritual action and costumbre as beliefs. As ritual action it represents their forebears' doings, those practices that "stem from the Inka time". I proposed that costumbre is thus a link with an Indian past which helps mark their distinctiveness from other groups and from non-Indians, and hence it has to do with tradition, with ethnicity and with identity. However, because of its quality of being action, albeit a particular kind of action, costumbre allows space for the Islugueños' talent to incorporate and re-formulate alien concepts. This theoretical perspective allows us to understand how and why different meanings may or may be not incorporated in the Islugueños' costumbres, which then act as 'repositories for identity'.

Although Islugueños are aware of the origin of certain practices, whether ancient or more recent, in ordinary speech all ceremonies are equally classified as costumbre. From the perspective of ethnicity, costumbre is a term coined for non-Islugueños and hence becomes a statement of identity. One axis of the transformation of everyday habits and beliefs into being classified as costumbre is the Islugueños' perception of their distinctiveness in comparison to Chileans.

With this ability to re-formulate concepts in mind, I found evidence of the proximity between present-day ethnography and some philosophical ideas already present in western thought at the time of the Spanish contact. A series of images of Christian representations of 'the soul' stroke me as close to Islugueños' explanation on how after death, three souls will go to different places: one stays with the loved one, another goes to Azapa and the third one stays with the bones (cf. Ortega Perrier 2001). In this article I contrast Andean ideas on the soul with ancient Christian iconography, I refer also to the image of the Virgin Mary and its relevance as source of life in the Andes and last but not least, I reflect on role exchanges between Saint Barbara and Saint James.

\section{Imagery and religious instruction}

The whole enterprise of Discovery was justified in terms of gaining souls for God. The encomiendas were organized around this principle, and colonial censuses even recorded people as 'souls' (Lafaye
1976). Like many Mediaeval and later Europeans, the indigenous people of America were illiterate, did not share a common vernacular with the missionaries, and even less did they speak or read Latin. In addition, Spanish was the language considered apt for the transmission of religious ideas (Hidalgo 1987). Hence, religious imagery must have played a transcendental role in the diffusion of Christian ideas during the evangelization period. Images and effigies (and dramatized performances) were used in both worlds as a means of overcoming difficulties in communication and to achieve evangelization (Gruzinski 1996: 186-188). The analysis of religious imagery seems particularly relevant to the issue of the relationship between Andean and foreign religious concepts, and of how knowledge may have been transmitted.

I recall Harris' description of the ladders placed on the graves of the Laymi (Bolivia), as well as the bread baked in the form of ladders which are also laid on the tombs in the Azapa cemetery of Arica. Figure 3 depicts the representation of the soul's ascent to Heaven on a ladder in Christianism.

I suggest that the social and cultural constraints on transmitting precise and immovable liturgy and theology imposed by different languages and illiteracy leave ample leeway for native creation, re-interpretation, appropriation and transmission of ideas that, through ritual and time, become costumbre: tradition.

There are some interesting similarities between concepts familiar to Europeans in the late Middle Ages and around the time of the Conquest, and Andean ideas about the nature of the soul, but as yet these have not received due attention. Connections between Catholicism and native beliefs have been analyzed with reference to Andean mythology (Silverblatt 1988; Dillon and Abercrombie 1988; Lafaye 1976; Gisbert 1980; Bouysse-Cassagne 1997), the social and personal circumstances of Spanish chroniclers are taken into account when ethnohistorians analyze their writings about Indian society, and the Spanish administrative and clerical organization is analyzed when studying colonial administration; in Andean anthropology, however, I have not noticed a similar preoccupation with analyzing the relationship between ideas ingrained in Andean cosmology and the products of the intellectual and theological climate of Europe at the time of evangelization. It is not easy to analyze this relationship, as one may fall into denying native 
creativity and the complexity and sophistication of Andean beliefs. However, Islugueño evidence highlights the need to treat 'change' as the product of processes affecting both local and wider societies.

I would now like to introduce some coincidences between native and Western concepts that have surprised me, though I cannot explain them fully in the present work. Islugueños' assertions of the existence of three souls may be an appropriation, or otherwise is an example of the proximity between Andean and European ideas of the time. For example, "... Hence three souls, in allusion to the above as combined in human beings..." (1601) "....I scorne it with my three souls..." (...) "The Embryo is animated with three souls... and these three in Man are like Trigonus in Tetragons" (c. $1645)^{3}$. These quotations indicate that belief in the trilogy of the soul was accepted well into the seventeenth century in England. However, this quotation remained obscure until I found a reference to Saint Thomas Aquinas's 'hilomorphism'. Hilomorphism defines the human being as a unity formed by two different elements: the 'raw material' (potentiality, Lat. Potentia) and the 'substantial form' (the actual form? Sp. el principio realizador); these two principles '... unite in the reality of the body and the soul of the human being...' Saint Thomas Aquinas developed this idea by accepting Aristotle's proposal that the foetus is first 'infused' (sic) with a vegetative soul, later with an animal soul, and finally, when the body is fully developed, with the rational soul. Each inferior 'soul' is overcome by the following, until the last is infused. The idea of the acquisition of 'one soul' at the moment of conception is relatively recent in Catholicism. As recently as 1812, the Church confirmed the idea of 'hilomorphism', hoping to overcome heretic trends that attempted to separate the soul's existence from the body's (Hurst 1993: 18-19; 22).

Allen (1988) states that Andeans' beliefs concerning the nature of the soul are incompatible with Christian ideas: she points out that the essential difference stems from the Western dualism of body and soul which go against her findings in which the soul often has a physical component (as in bones and hummingbirds) (p. cit. 62). It is interesting to note here that in Western thought the separation of body and soul has a precise historical origin. In the Old Testament the soul is related to the concept of 'breath' (likewise anima) and no reference is made to a distinction between 'body' and 'soul'. The
Christian dichotomy was introduced by St. Gregory of Nyssa and by St. Augustine.

We could speculate, as an example: how would an Islugueño forebear responds to this sixteenth-century (Figure 1) that depicts a human being with three other human figures inside his body? The inscription states that the theologian portrayed the 'old sinner soul' (as a woman-serpent), and the 'new innocent soul' (the child) born in Christ (the bearded figure above the infant). At least since Saint Augustine's time, Christian theology referred to the 'Three Powers of the Soul' (Potentia): the desire to do good, the evil inclination to resist, and the memory - the moral of the story, as it were. Complex ideas such as these may have been interpreted differently by people unable to decipher written texts. Illiteracy makes it difficult, if not impossible, to establish 'fixed' meanings, and without a common vernacular, attaining absolute accuracy in an explanation is not feasible. The scholar's concept of the soul like that of Potentia can only be grasped by those acquainted with theology; whereas most observers are likely to

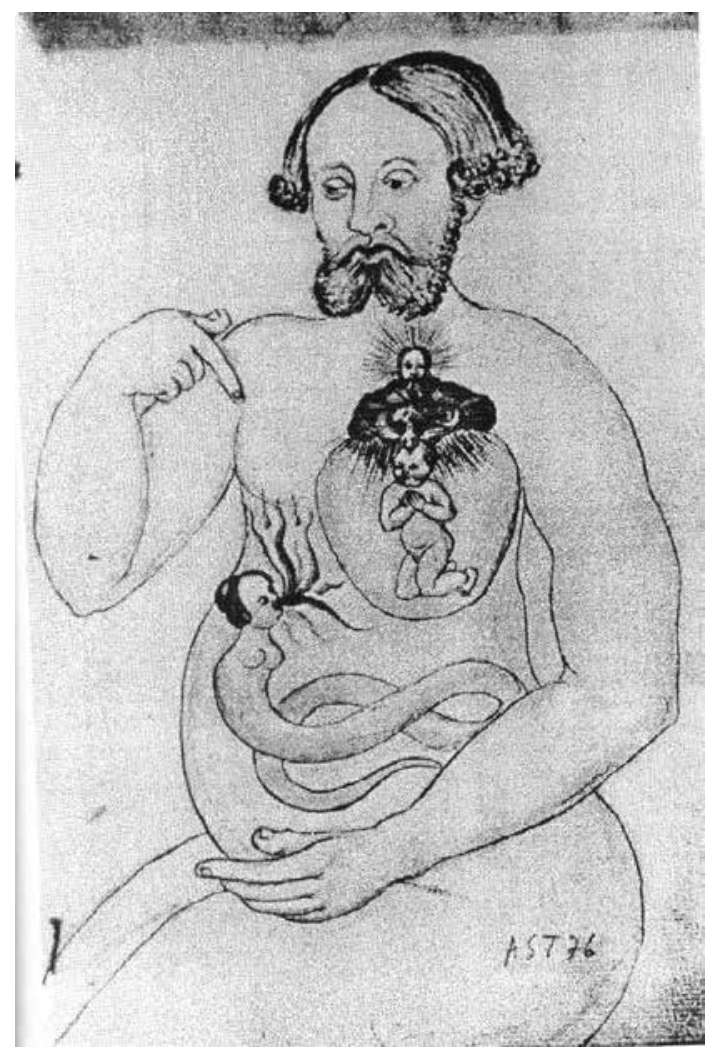

Figure 1. The Soul. Warburg Institute, U. of London. Woburn Square, London, WC1HOAB. 
interpret it as a man with three 'souls' inside. Andean tradition, whether in Bolivia, Peru or Chile, refers to humans as having 3 types or kinds of soul. In addition, I should remind the reader that in European languages the term 'soul' has been used in relation to plants and animals, hence the attribution of 'life' to nature, is not as foreign to western thought as it may seem to the anthropologist confronted with the animated landscape of the Andean people (Oxford English Dictionary 1986 Vol. Vll: 461).

The cited information indicates that the idea of three different stages of the soul (which is likely to be understood by laymen as three 'types' or 'kinds' of souls), was prevalent in the Catholic Church until after the evangelization of America. Islugueño Tata Marco's three souls are therefore similar to the Catholic doctrine on the nature of the human soul that prevailed until recently. Hence, the opposition between Andean and Christian ideas -that an Allen based on the latter's dualism of body and soul- needs to be seen in a historical perspective. Once this is done and it appears that this dualism is a historical acquisition and not intrinsic to Christian theology, the assertion of this 'opposition' may be relativized.

The proximity between concepts popular in western society about the time of the Evangelization of the Andes and current Andean ethnography, brings back into focus the relationship between costumbre as action (ritual acts), costumbre as beliefs (and hence attribution of meaning), and the possibility that ritualization implies for the change of meanings; hence ritualization theory also sheds light on how the re-appropriation of western ideas may have taken place in the Andes. In this light, the costumbre (belief) that attracts the attention of the ethnographer for its peculiarity may be seen as native re-interpretations of graphic representations of Christian ideas (Figure 2).

Using some written and pictorial sources, I have provided examples of the proximity between mediaeval and renaissance western concepts and the Andean conceptions of these. It is necessary to stress that I am not suggesting that the images I have used to illustrate my argument were those presented to Andean Indians by the evangelizers. However, if one takes into account the fact that imagery was indeed used in the conversion of Indians and that, moreover, religious iconography is conventional; it seems legitimate to assume that similar representations may have reached the people of the Andes.

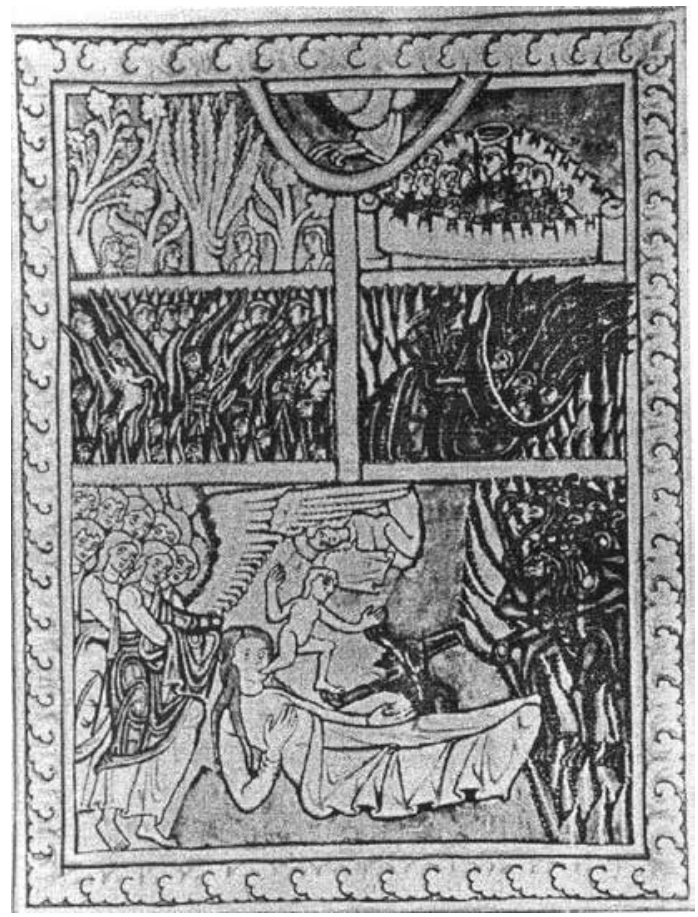

Figure 2. Soul leaving body of the dying. Warburg Institute, U. of London. Woburn Square, London, WC1HOAB.

\section{The fiestas, an occasion for ritualization}

The rich potential of ceremony in general and particularly of the fiesta to help with an understanding of social change and re-formulation of identity, is brought out when one realises that no records document the staying of Catholic priests in Isluga; such a presence may have encouraged us to attribute to Catholic devotion the appeal that the fiestas have held for centuries. In fact the contrary is the case: Islugueño devotion is maintained by indigenous rather than by Catholic impetus.

The high altitude and harsh climate of Isluga, compared to the much more benign valleys chosen for permanents settlement, make frequent contact with the Spanish priests unlikely. The four-day mule journey must have discouraged many devoted missionaries, as it did in the 1980s and during the following decades. Since the road was built in the 1960s, distance and lack of funding for the rural missions have further prevented an active Church presence. By the late 1970s, a Polish priest single-handedly took care of Camiña and Isluga. A military chaplain, he made clear that the purpose of his occasional visits was to eliminate all Aymara 'paganism' from the saints' 


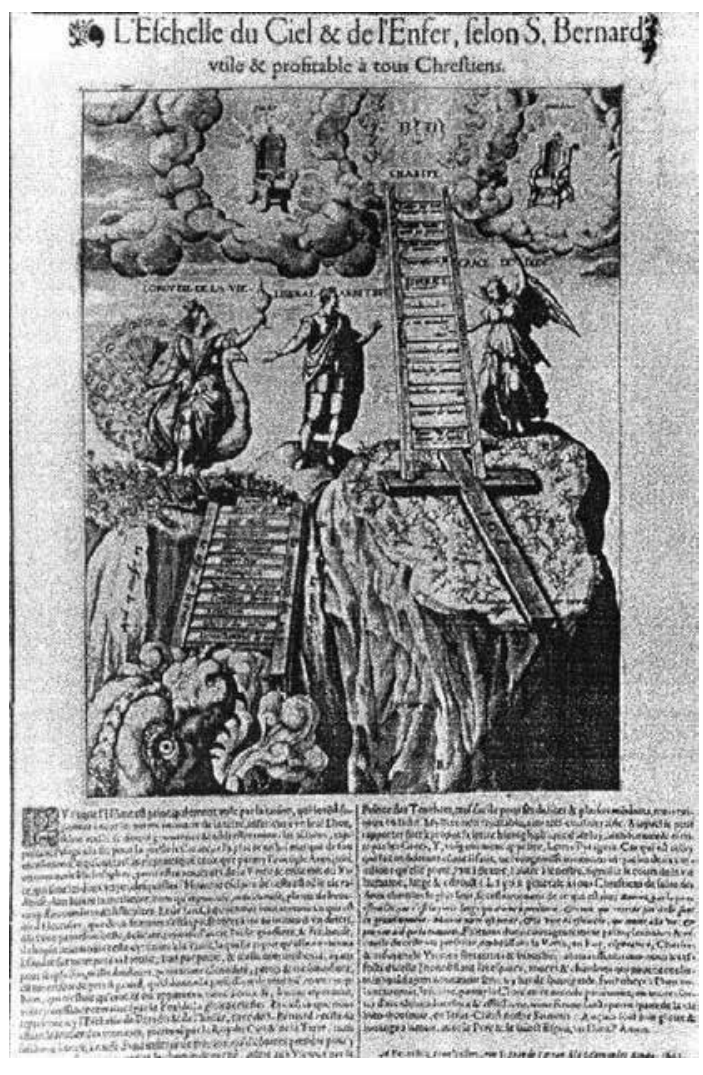

Figure 3. Stairs to Heaven. Warburg Institute, U. of London. Woburn Square, London, WC1HOAB

celebrations. Therefore, in retrospect the only source of a tradition of Catholic saints' fiestas must have been Camiña, the official administrative and religious division during colonial times.

In the sense of doctrine, the Catholicism known to the Isluga herders derives mostly from the teachings of priests residing in the valleys during the Spanish colonial period. Nowadays there are no priests in Isluga and there are few reasons to suspect that it might ever have been otherwise; in 1618 the Carmelite Antonio Vazquez de Espinoza informs his superiors that due to the distance of Tarapacá from Arequipa, these people had not seen a priest since the conquest, a claim that the historian Hidalgo considers exaggerated. Though in 1750 the priest of Codpa (closer to Arequipa) complains that:

'...The Indians had no recollection of Christian doctrine and its explanations. His parishioners did not partake in Bible reading or the sacraments...The churches lacked sacred vessels...[and] there were... annexes on the other side of the Cordillera that he could not reach since he was alone and without an Aymara assistant who would have been quite necessary for his doctrinal classes...' (Hidalgo 1987: 52-53).

Because of colonial organization, with its merging of political and religious administration, the 'official existence' of ethnic groups must have depended on their showing allegiance to Christianity.

To illustrate the importance attached to religious instruction, one should recall that censuses of the time were organized by doctrinas (Sp. doctrines), divisions attaching each of the different ethnic groups to a religious figure who was to be responsible for their conversion to Catholicism. With time, the power of the curatos (Sp. curas, priests) declined and the presence of priests in the Aymara-speaking area became rare. During the colonial period, some basic texts for evangelization were issued in both Andean languages, Quechua and Aymara, but I have not come across ethnographic references to them. By contrast, Hidalgo states that Spanish was the only language reported as suitable for expressing the Catholic theology and faith (ibid: 50). In addition to this reported lack of contact with the clergy in the past, it should be reminded that until fairly recently most Catholic ceremonies were conducted in Latin, and religious books were often written in this language. When this was not the case, Spanish was the official language, as Hidalgo states. Well into the twentieth century, most if not all Islugueños spoke Aymara exclusively and until recently all were illiterate. Hence, the attributes which the Islugueños ascribe to their saints and virgins must derive from oral tradition and visual representations. I thus assume that the original stories of the lives of the saints and the effigies in Isluga's church were interpreted in the Islugueños' own terms. I would like to stress that I am not speaking of religious syncretism or doctrinarian imposition but about re-interpretation and political re-appropriation.

Islugueños' claim that Saint Thomas came on foot from Camiña, and report that Islugueño sikuri musicians played during religious festivals in the Camiña valley. In other words, the fiestas I attended are to a large extent the product of generations of local ideological and social processing of a religious 'excuse'. Ritualization is made possible by the atmosphere provided by the fiesta system, where peculiar transformation of ordinary action takes place on such 
a large scale. Furthermore, as these celebrations are intrinsically related to the attainment of social maturity within the society, the fiestas become the most propitious field for the reproduction of the community of Isluga, facilitating the persistence of the group.

The fiesta, the celebration of a Catholic saint's day, follows certain patterns that include the use of music and the provision of food and drink for all those present. In the related cargo system, men and their spouses volunteer to sponsor the celebration and, with the help of the extended family, affines and ritual kin, are in charge of providing the necessary elements. Each celebration requires an alférez and a mayordomo and the fulfilling of such offices are a requirement for being considered a full adult member of the community. Saints' fiestas may celebrate the patron saint of a particular hamlet or they may involve the whole Community and will take place in the ceremonial hamlet, Pueblo Isluga. In Pueblo Isluga the cycle of the saints' fiestas in December used to comprise at least six celebrations. An old woman remembers: '... Concepción, Saint Barbara, Corpus, Otava [sic]...; Rosario and Saint Thomas. In addition to Carnival...Rosario and Otava were lost, a long, long time ago...' (Natividad Castro, 1983). In December 1979, more than 100 people attended the celebrations which lasted for more than a week, with guests coming back from the valleys and some from the coastal towns. The description provided by one woman is nostalgic: ' ...big earrings, silver pins on the decorated vest... [fiestas] meant a lot of work, I almost did not want to be a sponsor. People will come from everywhere, Camiña...[Another fiesta was] Pascoa, after Carnival; it represented the crucifixion and resurrection of Christ. The image was taken down from the cross, put into the sepulcher and afterwards unburied...' (Gregoria Flores, 1983). The Pascoa (Sp. Pascua, Easter) was still celebrated in 1980: a Pentecostal man remembers impersonating a 'devil' for two years before 'being converted' around that date.

Since the late 1970s the number of celebrations has consistently declined almost to the point of disappearance. In December 1979, in addition to Carnival and some hamlets' fiestas, I attended the celebration of the four main saints and virgins: Saint Barbara, Concepción, Corpus (Santísimo) and Santo Tomás. In 1981, there was a celebration for the Virgin Concepción and Saint Thomas. Saint Barbara and Corpus were neglected but caciques (heads of each moiety) were still elected. In the 1990s, caciques became a thing of the past, while migration and increasing conversion to Pentecostalism have turned Saint Thomas into a small fiesta. Although Carnival and Saint Thomas' celebration have somehow survived, the scope and size of these fiestas have definitely declined. The costumbres persist, but nowadays their performance is determined by the religion of the individual: a Pentecostal will not perform any costumbre.

I am not suggesting that prior to, or during the 1960s, the fiestas were 'fixed' phenomena; my data suggests precisely the opposite, that fiestas (like the rest of Islugueños' 'tradition') are marked by innovation. However, one cannot ignore the fact that in only a few years the fiesta cycle was dramatically altered. By the early 1980s, mature men recalled sponsoring six or more fiestas. They also remember the 1960s as a period of full operation of the fiesta system, whereas the early 1970 s seem to mark the threshold of their decline. These dates are consistent with the establishment of Chile's administrative apparatus (the Municipality) in Isluga, a system which introduced an increasing political and ideological bias towards the nationalism that characterized the military government from 1973 to 1990 , and that produced further change at the level of the local leadership.

A fiesta begins before the actual saint's day. Two days earlier both sponsors go to the calvario on a hill near the Pueblo. Once back from the calvario, they perform a wilancha in the front yard of the church, or in front of their houses, strewing animal's blood on the earth. At the same time, the main Uywiris are summoned in order to ensure the fiesta's good outcome. Islugueños usually start the sacrifice with a white llama and although these animals are slaughtered to provide meat, the killing is carried out in a devout manner and the sponsors participate by sprinkling alcohol and coca on the animals before the sacrifice. On the eve of the saint's day, preparations continue while the guests arrive. At sunset, the entrada de ceras (Sp. candles' entrance) is prepared, candles are lit and the images of the saints arranged to give due importance to the honoured saint. People stand or sit (women on the floor, and the alférez and caciques standing or kneeling close to the main altar), while the mayordomo and the verger act as though local priests. Sometimes branches of fragrant eucalyptus brought from the valleys are put on the floor or used to build arches. People stay up late into the night waiting for the day to come.

On the morning of the saint's day, the musicians play in front of the alférez's house and go in procession 
several times back and forth between the houses of the mayordomo and the alférez, and the church. Lijllas (woven cloths) and coloured llama-wool or sheep-wool blankets are placed on top of wooden tables or often on the floor, to serve as ceremonial tables, set in front of the sponsors' houses. The mesa is carefully arranged and each guest who wants to greet the sponsor goes to the table, takes coca leaves and drinks to the sponsor and the saint. The arrangement of ritual objects and the etiquette of the mesas follow a widespread Andean pattern. Facing the mesa and the East, with their backs to the door of the house, the alferez and mayordomo, escorted by the caciques, begin the celebration by kneeling and greeting first the saint and then all the Uywiris of Isluga, asking for protection and benediction. This is done by sprinkling pure alcohol and coca leaves for Pachamama and the Uywiris (Sacred places, mountain caretakers, sponsors. cfr. Martinez 1976). The sponsor's wife sits on the floor beside a simplified version of a ceremonial mesa. Women come to greet her and 'keep her company', and they are given coca leaves which they receive with both hands in a respectful attitude. Some leaves will be put into their own little woven bags (A. chuspas), others will be used to pautar. Pautar describes the offering of coca leaves by letting them fall softly from the right hand while pronouncing good wishes for the sponsors and naming the main protective entities. This series of ritual actions is also called amar ( $\mathrm{Sp}$. to love). Women then circulate their own chuspas in a clockwise direction, the other women taking coca leaves to chajjchar, that is, they put them in their mouths, with or without lime, and add sugar with one hand in a rapid motion. Afterwards, they kiss the chuspa softly and return it to the owner. Pure cane alcohol is circulated to ch'alltar (A. strew) to the Sacred Places:'...Laramkawani...Kawaraya... Qhorawanu... Chapillijsa...' This alcohol is carried in small glass bottles for the exclusive purpose of enabling people to exchange a sip with the more intimate circle of the sponsors, or for ch'alltar; it therefore has a different use from that of the diluted alcohol carried in kettles for the guests to drink. It is interesting to note that apart from strewing, the offering of pure alcohol to the Sacred Places includes passing the right hand quickly over the top of the bottle in their direction, seeming to send the fragrance of the alcohol (spirit) to them. This reminds me of the act of blowing $(\mathrm{Q}$. phukuy) on coca to direct the essence of the leaves (Q. sami) to the Sacred Places, practised in Peru
(Allen 1988: 127-130). All the while, mature men play the sikuris or the lichiguayos (large flutes similar to the Bolivian pinkillos), dancing around the circle of women (see also Stobart 1994: 40-43).

While the bands play, men and women with kettles full of alcohol and small tin cups offer drinks to the well-wishers. Finally, in the afternoon, people go to the church and the saint is carried out in procession. Saints' images are paraded in a full circle around the church; people stop and pray at each of the altars representing the ayllus (this was done even after the altars were destroyed). On the rare occasions when a priest is present, he attempts to fit a Mass in between and guide the procession. Most often the people are left alone, and discussions follow about the right Catholic procedure, in which the verger usually has the last word. Meanwhile, groups of young men playing panpipes compete with the more accomplished musicians who play brass instruments, providing the music which is a key ingredient of any celebration. Once the procession is over, people stay in the church for a while and afterwards they go out into the square where there is dancing and music. The day after the saint's day, food and alcohol are provided and socialising continues until late. During the farewell to the fiesta, called cacharpaya, dance and songs express sorrow at the departing celebration and joyful anticipation of the coming year's fiesta.

\section{What do we love? The saints}

'...I've told you half, of the half....Saint
Thomas looks after all of us. He is mirac-
ulous, he knows. I tell you this for you to
keep it in your heart. Ask the ones of the
lower Saya, ask Carmelo Choque or Antonio
Choque. They know... ' (Angel Castro,
December 1978).

Among Andean people, saints are regarded as part of this world. Contrary to Catholic doctrine, they do not inhabit the celestial realm but stay among human beings and the native pantheon. As explained elsewhere this (invisible) existence takes a different form, and like the people in the Peruvian and the Bolivian Andes Islugueños conceive of the saints as a close presence that belongs to God's sphere (Sp. Dios parte). Based upon the ritualization of action, I offer an interpretation of how Catholic celebrations may have become incorporated into the life of Islugueños. 
Islugueños consider the fiestas de santos as costumbres, in the sense that these are 'their own ways' of celebrating the saints. From the description offered, it becomes clear that costumbre (ritual action as a mark of 'Indianity') is a key element in the fiesta's performance. In contrast, although Catholicism is referred to constantly, one must bear in mind that the Islugueños' view of Catholicism has little in common with the main core of Catholic doctrine. Ritual acts are confined to a minimum, consisting of genuflexions, of making quick and incomplete signs of the cross, and the partial uttering of prayers. However, as a whole the ritual stance adopted makes these acts very convincing; and they certainly are the Catholic ritual for Islugueños - had I not been raised as a Catholic, I would not have noticed these 'flaws'. This is very much reflected in the Latin that I heard from the verger during All Saints' Day. It sounded like the Latin of the priests and it seemed irrelevant to the participants that the verger could not actually read the book he held. At least, I know that very old Tata Julian did not know how to read. In other words, it is not the Catholic belief or rite which is of central importance. I suggest that it is the Islugueños' 'practice of something that means something peculiar to them'. The Virgin of the Immaculate Conception is not important in itself; what Islugueños are recognising and re-enacting is the Virgin's maternal, generative, miraculous capacity to reproduce. Little elaboration is needed on our part to reach such an interpretation. Mother Earth, the Pachamama is more often called la Virgina (Sp. Virgen), the Virgin. If God is thus made man, the mountains can certainly speak and be powerful.

I would further suggest that the Islugueño version of the lives and miracles of the saints housed in their church and hamlets' chapels is probably based on the images, sculptures and visual illustrations that evangelists carried with them. Hence, although they are not accurate accounts of the saints' lives based on the Catholic gospels, they do instead provide clues to Islugueños' ontology, their history, their identity. Given that we have no way of knowing for sure the contents of sermons or formal instruction when (and if) friars reached Islugueños, these remain as speculative suggestions. For the sake of general argument, it must be kept in mind that the religious conversion of the Indians was also an administrative issue and thus represented a way of accessing and controlling labour and resources for the Church and the encomenderos, for the colonial vaults and later for the Republic (Hidalgo 1987: 51). That is, it entailed the ritualization of power.

\section{Saint Barbara (and Saint James)}

In Isluga, Saint Barbara is more often than not called a virgin. The only female saint whose fiesta forms part of my ethnography, her relevance for Islugueños is shown by the persistence of her celebration, second only to the Virgin of Immaculate Conception. In everyday speech, the two beautiful images, Bárbara and Concepción, are equated. In trying to find the analogies that allow this equivalence, I came across the fact that apart from the similarities of gender and appearance between the two images, the story of Barbara recalls a young maiden who was imprisoned by her father to stop her from meeting her suitors: a virgin. During her father's absence the maiden became a Christian and decided to live as a hermit. Saint Barbara was condemned for her piety and was subsequently beheaded. In punishment for his cruelty, the father was struck by lightning and died. Devotion to Saint Barbara was widespread following the late Middle Ages, and during the seventeenth and eighteenth centuries she was much represented, often with the tower where she was imprisoned (Figure 4). Her name was invoked for protection against sudden death such as that caused by a lightning-bolt, and consequently she became the patron of those exposed to '...coups de la foudre...' (Hugh Farmer 1978: 28). In De Lapparent's words:

'...the lightning-bolt smashes to pieces the body of the criminal [the father, a parricide] and throws his soul to Hell...It is only one step from lightning-bolt to cannon-fire. Since the invention of gunpowder...artillery soldiers are under her protection... [also] miners and fire-fighters' (De Lapparent 1926: 38-39, 60-61. In French in the original, my translation).

Barbara received the devotion of the Spanish artillery and was not surprisingly sometimes represented holding a lightning-bolt in her hand; most often, with heavy clouds and a lightning-bolt behind her (see fig.5). In Sonqo, her feast is dedicated to the Apu Qhaqha; qhaqha in Quechua means:'...a place that has been struck by lightning...' (Allen 1988: 242, 262). For Islugueños, who are herders 


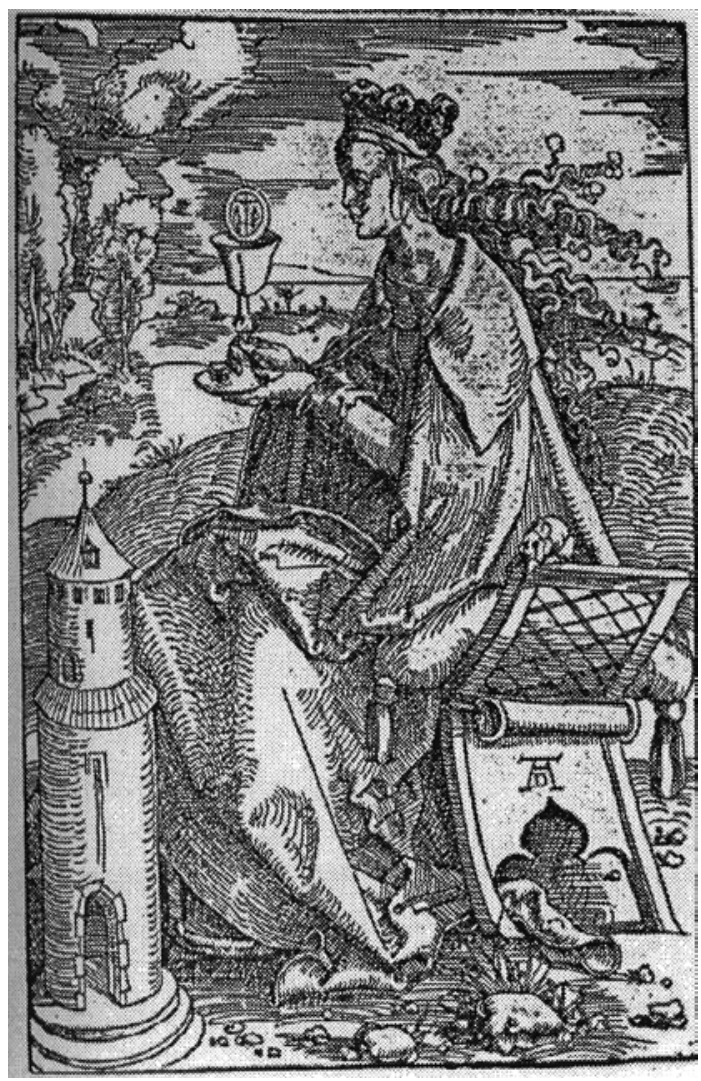

Figure 4. Saint Barbara, Virgin. Warburg Institute, U. of London. Woburn Square, London, WC1HOAB

and subsistence agriculturists and who relied upon bartering these products in order to supplement their diet, survival depended on the rain that fell during the summer: the time when the lightning strikes. A woman from Isluga said:

'...Nowadays few people come and many fiestas are no longer celebrated. [Saint] Barbara had rain, maybe that is why there is no rain now, and there are plagues on the crops... (Gregoria Flores, 1983)

During the cycle of fiestas in December, Barbara and Santísimo are paraded together. The alternative name of the Santísimo is Corpus Christi, the body of Christ which is in turn identified with the sun. God is equated with the sun in a straightforward association: the reliquary containing the body of Christ (Santísimo) is made of silver in the form of a shining sun. In Isluga, Saint Barbara is always referred to in association with Corpus: as Corpus t'alla, the female of Corpus, a metaphor for the inter-dependency between the lightning bolt (that connects this time and space with the Arajj pacha) and a distant sun (which makes things grow). On the other hand, the representation of Barbara with a tower which resembles a church building may also be regarded as representing the establishment and acceptance of Catholicism in Isluga.

I must now bring into the discussion yet another saint to further clarify my interpretation of Barbara's role in Isluga. San Santiago (Sp. Saint James) is widely venerated in the Andes and overtly associated with the lightning-bolt. Like Saint Barbara, he was one of the favorite patrons of the Spanish soldiers and was most often illustrated killing Moors. Transformed by the Indians, San Santiago incarnates the power of ancestral Andean deities (Silverblatt 1988: 175). The re-interpreted Saint of the vanquished Andeans, Santiago represents the possibility of attaining power and is thus more of a dynamic creation than a simple merger of religious beliefs; in my view this is a political statement.

Santiago is also highly relevant for Islugueños as a determining figure in the ritual empowerment of the caciques and in the layout of Islugueño ethnicity. Surprisingly, he is not celebrated in Pueblo Isluga, though a small effigy of the saint is kept in the Pueblo Isluga's church and in Enquelga's chapel; at a local level in the $Q$ 'orawani hill, a novena is named after him. I suggest that, for Islugueños, Barbara stands metaphorically for Santiago, and that just as Santiago is transformed from a mythical Indian-killer into the personification of ancestral power, Islugueños transform the prisoner of a parricide father into a generative (fertile female), rain-bringing figure. This idea is further supported by Dominican chronicler Remesal, who wrote that Mexican Indians '...did not know whether Saint James was a man or woman...' (Lafaye 1976: 199).

There is further evidence of the 'transference' of Santiago's powers to other saints. In Enquelga, Dransart reports that Saint Andrew is called Lord of the Rains and that in the past the dance performed at his celebration imitated streaks of lightning. This author states that Santiago is the saint of the strong winds, but adds that the novena placed on top of the Q'urawani hill is dedicated to Santiago, and that the name of the hill translates as 'the place of the slings'. My own data points to a clearer association of Santiago with rainfall. However, the information is to be seen as complementary, as Dransart also warns about the flexibility of the correspondences 
between meteorological phenomena and the saints (2002: 54-56).

Returning to Saint Barbara, the ritual importance attributed to Santiago is in too open a contradiction with its relative lack of appeal in contemporary Isluga. It should be recalled that in the Andes sacred entities are classified along the lines of masculine and feminine complementarity (Gavilan; Carrasco 2009). In this sense, Barbara may stand as the t'alla of Santiago who 'lives' in Sabaya, and to whom Islugueño caciques go on pilgrimages. I hence suggest that Barbara's relevance, vis-a-vis the scarcity of images of San Santiago - and his relative unimportance reflected in the fact of his not having a celebration in Pueblo Isluga - may point to the previous existence of ethnic links with Bolivian ayllus. Hints on the existence of such a relationship are reiterative and shall be understood in the context of the traditionally difficult relationship between Bolivia and Chile. Expressing allegiance, however symbolically, to one of Chile's traditional rivals is not a luxury the Islugueños could afford.

With respect to the Virgin Mary images, the leeway for interpretation provided by the image of a beautiful lady in a light blue robe, standing on clouds where cherubs float, is ample. The self-generating notion of the Immaculate Conception is too close to the capacity attributed to the Pachamama, from whom life springs. In terms of religious pictography, the Immaculate Conception (Figure 6) is portrayed as a lady stepping on the head of a serpent, the kind of vermin that populate the Manqha Pacha or lower places (Grebe 1981: 69). This enhances Mary's similarity to Pachamama also present in this world and in Manqha pacha. Here Mary appears as an entity able to transcend the different realms; in the case of the Assunta, the Assumption of the Virgin that represents Mary suspended in heaven surrounded by clouds, she appears as an intermediary with the upper world (Figure 5). Assunta is venerated in August, at the time of the planting season, and is overtly identified with Pachamama. The Virgin Mary thus assumes a double character: autonomous life-giver as Mother Earth but also an entity able to transcend time and space to the Lower and Upper Pacha; as such she can make rain fall. Islugueños group together virgins and saints and call them all 'santos'. Considered in this way, the Virgin also lives in this world.

Another lead for understanding the ambiguous nature of Mary is provided by costumbre. I have

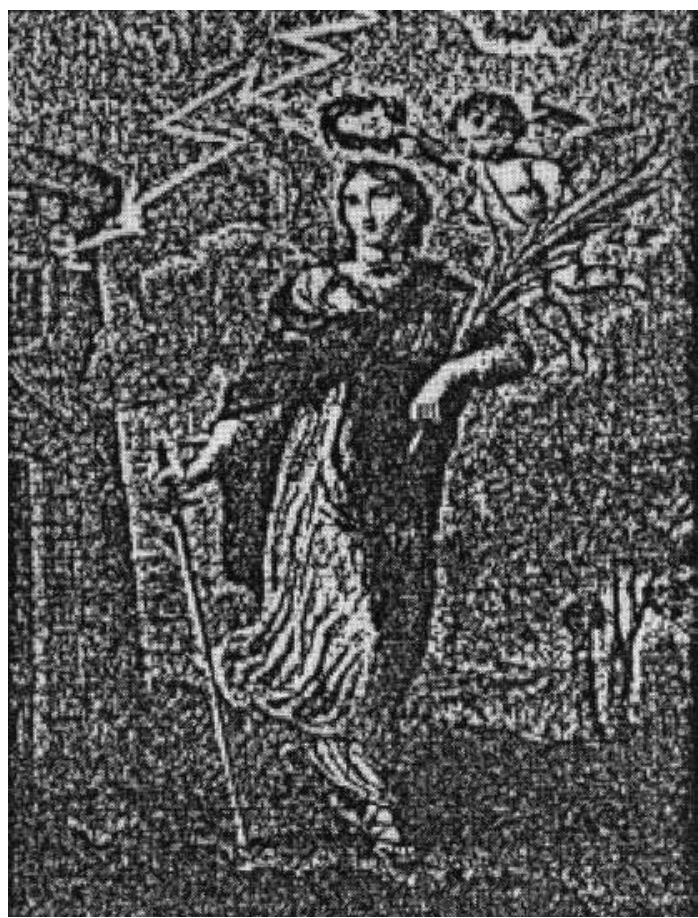

Figure 5. Saint Barbara and the lightening Bolt. Warburg Institute, U. of London. Woburn Square, London, WC1HOAB.

already analysed costumbre as providing clues to the diversity and change of meanings attributed to ritual actions, depending on their context. In the Andes, the souls of dead children are believed to inhabit heaven and to have an active role in looking after God's irrigation system (Harris 1982: 64). This costumbre strengthens the relationship between the Virgin and rainfall; in her portraits, the Lady is shown looking after the children. Symbolically, the children of the Virgin are close to Arajj Pacha and hence to the peaks associated with rainfall. In addition, the dead bodies of unbaptized infants are regarded as belonging to wilderness (Q. muru wawa, see Dillon and Abercrombie 1988: 63-64; Harris 1995a; Bouysse-Cassagne and Harris 1987).

So far my interpretation has been based on Catholic imagery in the context of costumbre and Catholic exegesis. I was fortunate enough to come across an image of the 'Virgin of Cocharcas', a Peruvian colonial painting (eighteenth century). The inscription reads: '...Of Cocharcas you are named Virgin Saint, Origin of Life, you are a sea of Grace and the Source of Water...' (My translation. '...De Cocharcas sois nombrada Virgen Santísima, Causa de Vida, eres un Mar de Grasia [sic] y Fuente de 


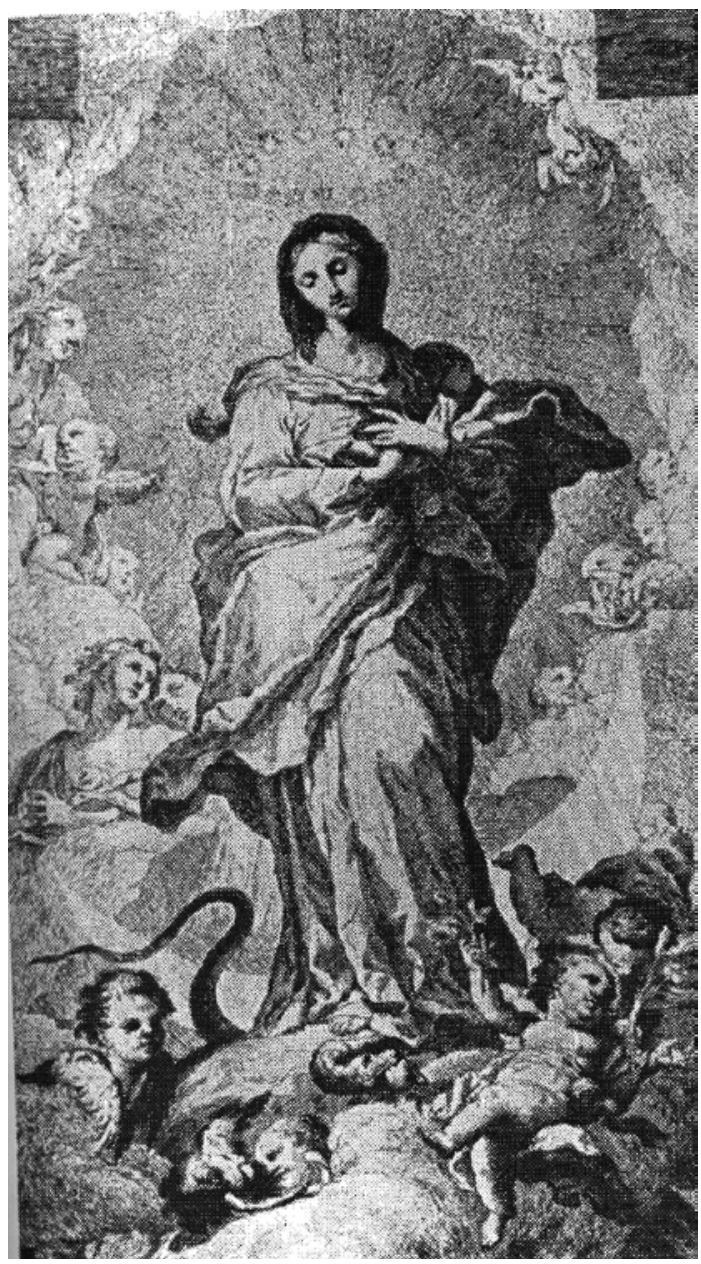

Figure 6. Virgin Conception. Warburg Institute, U. of London. Woburn Square, London, WC1HOAB.

Agua..., Figure 7). On the other hand, several authors refer to Andean identification of the Virgin Mary with the moon (Martinez 1976; 1989: 132; Grebe 1981). Dransart (op. cit.) explores the relationship between the Virgin and God, as celestial herders of Islugueños' camelids (see also Harris 1995c: 297). I suggest it is very likely that this analogy is mediated by religious iconography - conventional by definition - in which Mary is often portrayed standing on a crescent moon (Figure 8). If one pushes the metaphor further, the relationship between celestial cycles and women's menstrual cycle on the one hand and between fertility and the waters associated with birth on the other, is most likely. Hence, water may be regarded as both the origin and final destiny of life, of the animating essence.

Last but not least, while examining representations of the Virgin Mary I came across an image of

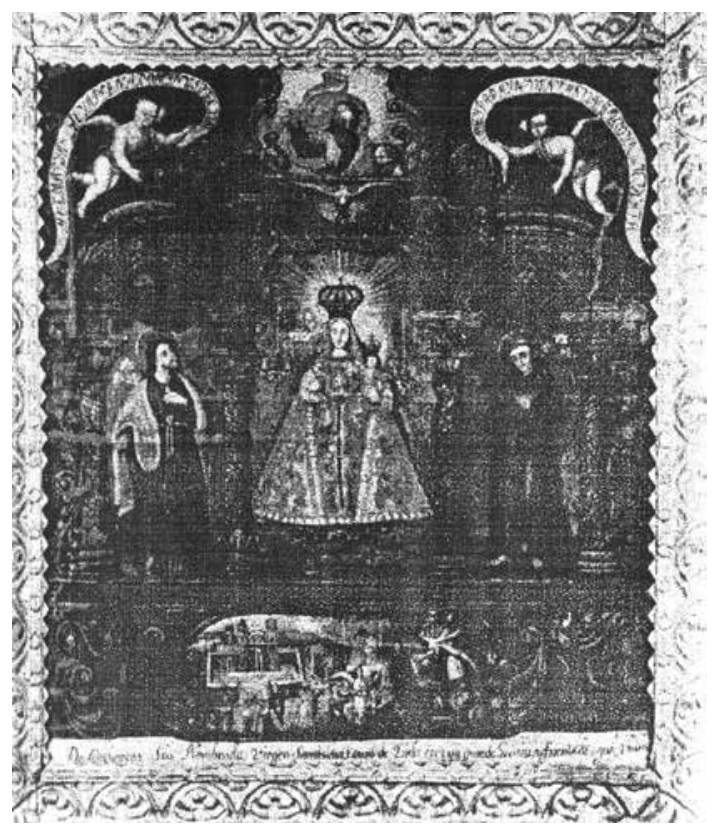

Figure 7. Virgin of Cocharcas. Warburg Institute, U. of London. Woburn Square, London, WC1HOAB.

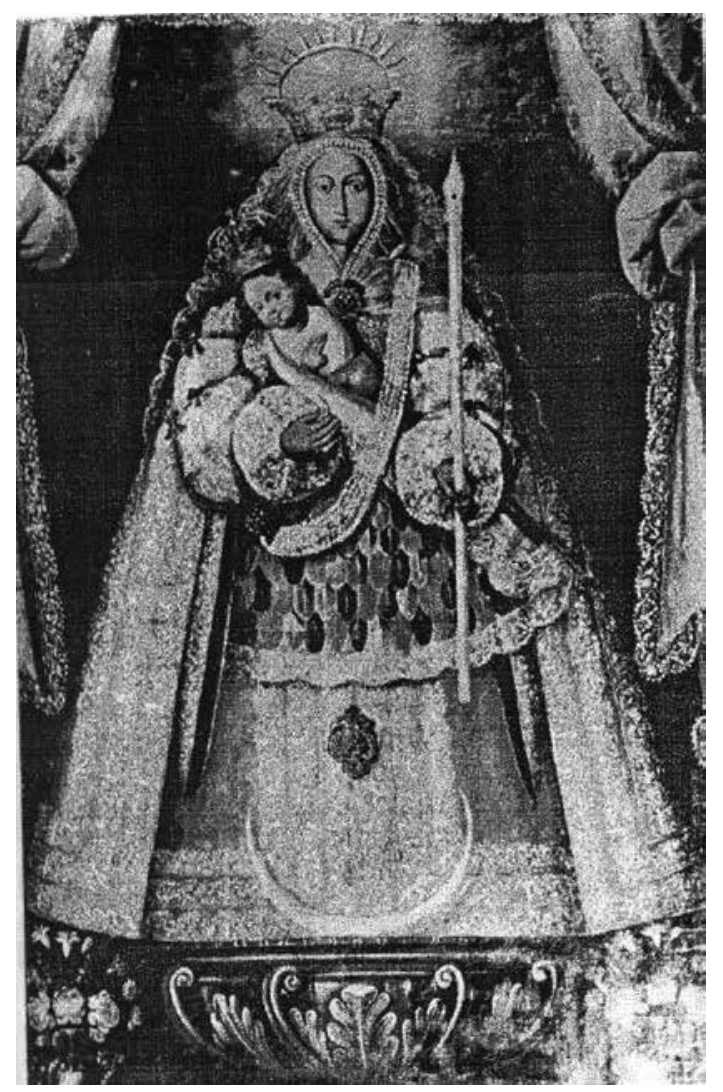

Figure 8. Virgin and the Moon. Warburg Institute, U. of London. Woburn Square, London, WC1HOAB. 
the Candelaria (Candlemas, the Purification of the Virgin) which was celebrated in Isluga's hamlets. I found out that the Candelaria is called the 'Virgin of Sabaya' after the neighbouring territory of Sabaya in Bolivia (Figure 9). In addition to the pilgrimage that caciques must perform to Yunguyo, also in Sabaya, the celebration of this Virgin suggests the pre-existence of an important relationship between Isluga and Sabaya. If we add this information to our analysis of Saint Barbara (as the t'alla of Santiago, who lives in Sabaya), and to the fact that when summoning the Sacred Places Tata Sabaya is often mentioned, the possible existence of a previous ethnic allegiance expressed symbolically becomes increasingly likely. As has been already mentioned, any allusion to such a relationship is avoided, as it may jeopardize Islugueños' recognition as part of the nation and hence their rights to territory and identity as Chileans. Although symbolic expressions in themselves are not to be regarded as historical accounts they may make up an integral part of them (Rappaport 1990). I hence remain faithful to my initial view of the fiestas as the

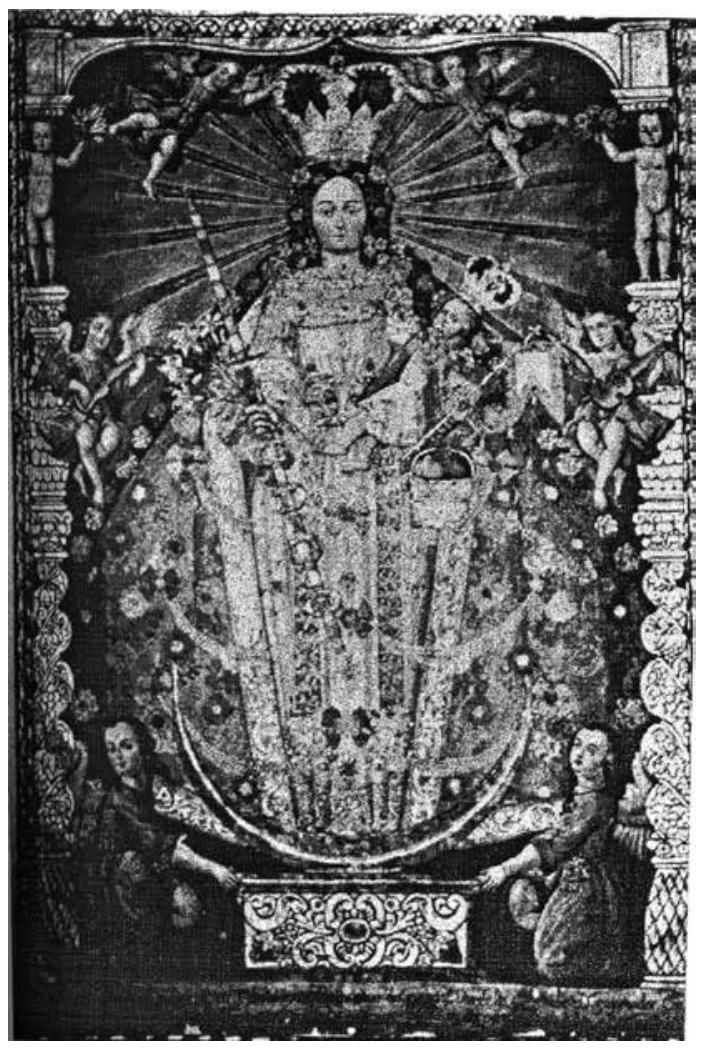

Figure 9. Virgen de Sabaya. Warburg Institute, U. of London. Woburn Square, London, WC1HOAB. celebration '...of something that means something important to Islugueños...' which helps to construct the Islugueños' identity, and therefore in this text I cannot ignore these clues to Islugueño history.

\section{Conclusion}

This analysis of the virgins and saints of Isluga supports my perspective on the dialectics between native and imposed beliefs and their historical contexts, and hence on the re-interpretation and appropriation of meaning through ritualization.

In sum, it is possible to find indications about the ways in which Islugueños have dealt with external impositions and foreign power by following the clues to ideology provided in the performance of the saint's fiestas. In this light, this society does not appear conservative and rigidly structured but on the contrary, seems to have sufficiently wide and flexible resources for the re-formulation of identity, in response to structural changes that demanded external manifestations of allegiance. The whole concept of 'tradition' as a source of identity adopts a much more dynamic aspect. Seen in this way, the 'tradition' of the Islugueños has the capacity for change at its core, as an integral part of its definition. What is being enacted, allowed by the 'empty time/ space' - the timeless simultaneity - of the fiesta, is a set of meanings and issues that are ingrained in Islugueños' daily preoccupations: (re-) production and (well-) being. Moreover, it permanently asserts their native organization, their social layout, 'practicing' it through the combination and balance of forces sought in the allocation of offices between the moieties. They do it, wisely, in the language of the dominant powers. The fiesta system could continue while the main structure was maintained, however reduced it might have become. As long as the combination of Earth (Virgins), heaven (Corpus and ascended Virgins), the intermediary who acquires the attribute of lightning (cacique and/or Saint Barbara, also a virgin) and the Community (Saint Thomas) was kept, it was possible to make sense of this basic structure. The welfare of the community, ensured by ritual propriety, could be guaranteed. The fiestas' decline and virtual disappearance can only be understood when one realizes the effective blow that Pentecostalism and the nationalistic ideology aimed at the heart of Islugueños' ritualization processes. 


\section{References Cited}

Allen Allen, C.

1988 The Hold that Life Has. Smithsonian Intitution Series, Washington.

Bouysse-Cassagne, T.

1997 "De Empedocles aTunupa: Evangelización, Hagiografía y Mitos", in T. Bousysse-Cassagne (ed) Saberes y Memorias en los Andes. In Memorian Thierry Saignes. Institut des Hautes Etudes de l'Amerique Latine and Institut Francais d'Etudes Andines. Paris, Lima, pp. 157-212.

Bouysse-Cassagne, T.; Harris, O.; Platt, T.; Cereceda, V. 1987 Tres Reflexiones sobre el Pensamiento Andino, Hisbol, La Paz.

De Lapparent, Le Comte

1926 Saint Barbe. L'art et les Saints. Henri Laurens, Paris.

Dillon, M. and Abercrombie, T.

1988 "The Destroying Christ: An Aymara Myth of Conquest", in Jonathan D. Hill (ed.) Rethinking History and Myth. Indigenous South American Perspectives on the Past, University of Illinois Press, Urbana and Chicago.

Dransart, $\mathrm{P}$.

2002 Earth, Water, Fleece and Fabric: an Ethnography and Archaeology of Andean Camelid Herding. London and New York: Routledge.

Gavilan Vega, V. y Carrasco G., A.

2009 "Andean Festivities and Religiosity in Northern Chile" Chungara-Revista de Antropologia Chilena Volumen 41, $\mathrm{N}^{\circ} 1$ : 101-112.

González Cortez, H.; Gundermann Kröll, H. y J. Hidalgo Lehuede 2014 "Comunidad Indígena y Construcción Histórica del Espacio entre los Aymara del Norte de Chile". Chungara, Revista de Antropología Chilena, Volumen 46, $\mathrm{N}^{\circ}$ 2: 233-246.

González Cortez, H. y Gundermann Kroll, H.

2009 Land Property Right Access, Community and Collective Identities Among Aymara Communities in Northern Chile (1821-1930). Chungara-Revista de Antropologia Chilena Volumen 41, $\mathrm{N}^{\mathrm{o}}$ 1: 51-70.

Grebe Vicuña, E.

1981 "Cosmovisión Aymara". Revista de Santiago. I. Municipalidad de Santiago, Museo Nacional B. Vicuña Mackenna, Santiago, Chile. pp. 61-79.

Gruzinski, S.

1996 The Conquest of Mexico. Polity Press, London.

Harris, O.

1995 "The Sources and Meanings of Money: Beyond the Market Paradigm in an Ayllu of Northern Potosí”, in B. Larson and O. Harris with E. Tandeter (eds.) Ethnicity, Markets, and Migration in the Andes. At the Crossroads of History and Anthropology. Duke University Press, Durham and London.
Hidalgo, J.

1987 "Indian Society in Arica, Tarapacá and Atacama, 17501793, and its response to the Rebellion of Tupac Amaru". Ph.D. Thesis, U. of London. Ms.

Humphrey, C. and Laidlaw, J.

1994 The Archetypal Actions of Ritual. Oxford Studies in Social and Cultural Anthropology. Clarendon, Oxford.

Hurst, J.

1993 La Historia de las Ideas sobre el Aborto en la Iglesia Católica: lo que no fue contado. Católicas por el derecho a decidir, Edinor. Montevideo.

Hugh Farmer, D.

1978 Oxford Dictionary of Saints. Oxford University Press, Oxford.

Lafaye, J.

1976 Quetzalcoatl and Guadalupe. The formation of Mexican National Consciousness, 1531-1813. The University of Chicago Press, Chicago.

Martínez, G.

1976 "El sistema de los Uywiris en Isluga", Homenaje al Dr. Gustavo Le Paige, S.J. Universidad del Norte. Antofagasta, pp. 255-329.

Martínez, G.

1975 "Características de orden antropológico y socioeconómico de la Comunidad de Isluga (I Región)", Tarapacá en el espacio y el tiempo. Revista Norte Grande Vol. 1, No 3-4.

Ortega Perrier, M.

1998 "By Reason or by Force: Islugueno Identity and Chilean Nationalism", unpublished doctoral thesis, Cambridge: University of Cambridge.

Ortega Perrier, M.

2001 "Escatología Andina: metáforas del Alma", Revista Chungara 33 (2). Universidad de Tarapacá, Departamento de Arqueología y Museología, Arica, Chile, pp. 253-258. ISSN07161182.

Oxford English Dictionary

1986 Vol. VII, Oxford.

Rappaport, J.

1990 The Politics of Memory. Native Historical Interpretation in the Colombian Andes, Cambridge Latin American Studies, Cambridge.

Silverblatt, I.

1988 "Political Memories and Colonizing Symbols: Santiago and the Mountain Gods of Colonial Peru", in Jonathan D. Hill (ed.) Rethinking History and Myth. Indigenous South American Perspectives on the Past, University of Illinois Press, Urbana and Chicago.

Stobart, H.

1994 "Flourishing Horns and Enchanted Tubers: music and potatoes in highland Bolivia", British Journal of Ethnomusicology. Vol. 3, pp. 35-48.

\section{Notes}

1 Some of the figures appeared in an article from the author (Ortega Perrier 2001). All of the religious representations belong to the Warburg Institute at the University of London, and were duly authorized.
2 Cfr. Ortega Perrier 1998, Chapters 3 and 4. Doctoral Dissertation, ms.

3 Oxford English Dictionary 1986 Vol. Vll: 461. 